\title{
The surgical pathology of cancer: a historical review
}

\begin{abstract}
Current literature reveals that it was around 1840 that the microscope evolved into a research tool. Therefore, I reviewed the extant older literature from a number of interesting angles. These included how the surgical specimens were not only obtained but also examined. It was shown that cancer nomenclature matured with time. Associated perspectives concerned the beginnings of museums and monographs. Outstanding among the latter was the well titled Surgical Pathology of French origin. The English translation was of 1832 vintage. Apparently, enrichment of microscopy had to await the resurgence of anesthesia and asepsis. As to the present prospects, it has been recommended that "students should be taught pathology, as they are taught surgery, on patients whom they know and on specimens that have recently been removed from patients still in the ward."
\end{abstract}

Volume 2 Issue 3 - 2015

\author{
Wilson Onuigbo \\ Medical Foundation and Clinic, Nigeria
}

Correspondence: Wilson Onuigbo, Medical Foundation and Clinic, 8 Nsukka Lane, Enugu 40000 I, Nigeria, Tel 2348037208680,Email Wilson.onuigbo@gmail.com

Received: December 10, 2014 | Published: April 06, 2015

Keywords: cancer, surgery, specimen, history, prospects

\section{Introduction}

Recently, Kalderon" noted that "By 1840, the microscope had evolved into a research tool." In much the same vein did other medical historians write. Thus, Hayward ${ }^{2}$ mentioned that, not until 1836, "were the common tumors differentiated microscopically" by Johannes Muller. Or, as Fisher \& Hermann ${ }^{3}$ perceived it, "The impact of the optical microscope was not appreciated until the middle and latter part of the nineteenth century." Moreover, Kardinal ${ }^{4}$ in his Outlines of the History of Cancer, considered that the "Birth of Microscopic Pathology" spanned from 1838 to 1900 . Indeed, both Sigerit ${ }^{5}$ and Ackerknecht ${ }^{6}$ were modern authors who appreciated the early trends. Therefore, this paper sets out to review the various perspectives of the practice of Surgical Pathology before 1840 with a note as to the prospects.

\section{Procurement of the surgical specimen}

For long, what was practiced was cadaveric inspection. ${ }^{7}$ On this account, practical morbid anatomists must have made some observations there from. In other words, closer observations were yet to be made on the surgical specimen itself. Thus, as Rothstein appreciated it. ${ }^{8}$ When he dealt with the evolution of Pathology as a Specialty in American Medicine, "The major scientific limitation of early pathology was its dependence on observations with the naked eye, which could produce only a limited number of useful findings." What enhanced such later day findings? Truly, in the 1835 edition of John Hunter's Works, ${ }^{9}$ the injunction was that, in order to obtain a proper specimen, "the incision must be extended to surrounding parts, and this is not for convenience, but for the success of the operation." Apparently, as in the case reported by Norris ${ }^{10}$ in 1820 , only the bulk of the lesion was being removed. In this context, the appropriate surgical practice was fostered when emphasis began to be placed on complete excision of the tumor. In Freind's ${ }^{11} 1725$ work, surgery was recommended when the tumor was "in such a place, where it may be entirely destroyed and eradicated." In fact, le Dran's ${ }^{12} 1749$ phrase was "intirely extirpated." Thus, the standard expression was for the tumor to be "completely removed." ${ }^{13,14}$ Alternatively, Thomas ${ }^{15}$ called it "complete extirpation" and Scarpa ${ }^{16}$ "radical extermination." Moreover, in the words of Cooper" "no glandular structure, nor any of the roots should be allowed to remain." Indeed, as Dawson ${ }^{18}$ perceived, "the whole of it ought to be taken away, so as to leave no atom of the disease."

\section{Examination of the surgical specimen}

John Pearson ${ }^{19}$ in 1793 wished for the availability of "discriminative characters" because precision would thereby "enable the practitioner to decide upon every case with clearness and confidence." His contemporary, Matthew Baillie ${ }^{20}$ prefaced his book thus: "Another advantage arising from a more attentive observation of morbid structure is, that we shall be better fitted to detect diseased alterations in the organization of parts which are but little, or not at all known." In his own view, Graves ${ }^{21}$ held that knowledge should advance so that "facts, now apparently single and insulated, would serve as nuclei round which future experience and observation might cluster together." Scarpa's ${ }^{16}$ experience was in terms of the specimen being "soluble in a great degree in warm water, and coagulable by acids and boiling." Incidentally, Muller ${ }^{22}$ was the authority who documented "cells" appropriately, while Bell ${ }^{23}$ loosely mentioned "cells" twice in 1816 when he performed postoperative injection and maceration of some specimens. Earle ${ }^{24}$ resorted to "washing it for some time" and noting the turbidity of the water. Todd ${ }^{25}$ in 1835 summed up what was happening during the beginnings of the century as being due to "the enlightened spirit of observation." His contemporary, Davies, ${ }^{26}$ cut the specimen "in fine slices" and concluded that "its consistence is similar to that of brain, but is less supple and breaks more easily." Earlier, Travers ${ }^{27}$ tackled the specimen by "floating (it) in water, and still more by certain maceration." Moreover, he noted appearances which were "invisible to the naked eye, and very conspicuous under a magnifier." Carefully, Carswel1 ${ }^{28}$ in 1834 employed "minute anatomical examination" and concluded as follows:

When therefore, we examine anatomically a mass of carcinomatous matter contained in a large vein, or situated on the surface of a serious membrane, in loose cellular tissue, on the surface of a sore or cicatrix after the removal of an organ affected with carcinoma, we find it composed of the following elements in various proportions, viz. Carcinomatous matter; cellular, fibrous and serous tissue; and blood vessels.

\section{Cancer nomenclature}

Cancer "matter" appears to have been the oldest designation for malignancy. Way back in 1790 , Crawford ${ }^{29}$ wrote in his contribution to the Royal Society that the awful role of cancerous matter was "well known." The varied perceptions noted by Young ${ }^{30}$ in 1805 ran 
thus: "In one instance it is asserted, that the matter of this disease is specific"; in another, that its action is constitutional; in a third, it is spoken of as hereditary; a fourth considers it as transitive; and, in a fifth, it is thought to be of a critical tendency." "Matter" per se was the appellation used by Howard ${ }^{31}$ in 1811 and it appeared in what must have been the reigning 1803 text, namely, the Edinburgh Practice of Physic, Surgery, and Midwifery ${ }^{32}$ Actually, "matter" often stood on its own. ${ }^{33-35}$ Davies $^{26}$ in 1835 declared as follows: "when it is fully developed it is homogenous and very similar to the substance of the brain." Andral ${ }^{36}$ in 1831 called it "putrid" matter. Of course, there were variations such as when Johnson ${ }^{34}$ in 1810 called it both plain "matter" and even "supposed matter." On this part, Thomas ${ }^{15}$ went further with "specific cancerous matter," while in $1833 \mathrm{Kerr}^{37}$ called it "cerebri form matter." And, by 1836, both Hodgkin \& Graves ${ }^{38,39}$ referred to it as "particular matter." Hey ${ }^{14}$ preferred "brain-like" matter. Another name was plain "substance" 40 whereas "peculiar" substance was used by both Bell \& Bichat. ${ }^{23,41}$ Incidentally, Mackintosh ${ }^{42}$ agreed with "melt-like" cancer, the name approved by famous Monro himself. As for Bright ${ }^{43}$ he named it "peculiar deposit." In sum, the descriptive terms varied clumsily until microscopy became authoritative.

\section{The museum perspective}

Sir Everard Home ${ }^{44}$ the son-in-law of John Hunter, in 1805 reported that Hunter did retain an excised breast tumor in keeping with his enthusiasm for museum preservation. So did Cooper ${ }^{45}$ who in 1829 successfully removed "the tumour, which is preserved in the collection at St. Thomas Hospital, (and) weighed 14 Ibs. 10 ounces." In another case of his that weighed 13 pounds, Cooper $^{17}$ mentioned the first step thus: "I will bring the removed part down with me, in order that you may be masters of the appearances which are produced in the breast, under this state." A complete set was that of Hodgkin ${ }^{7}$ which went back to 1829 being depicted in "A catalogue of the preparations in the anatomical museum of Guy's Hospital." Incidentally, since one of the preparations was the thoracic duct, which was noted to be "double in the middle," both autopsy and surgical materials were being accumulated.

\section{Flurry of monographs in the I830s}

This paper started with the view that it was not until 1840 that "the microscope had evolved into a research tool". ${ }^{1}$ One way of assessing this dated view is to consider the data recorded in the previous decade. In fact, during it, there was a flurry of monographs. The personally sighted ones may be listed chronologically as follows:

a. 1831 - Andral G. A Treatise on Pathological Anatomy. Transl. from the French by R. Townsend \& W. West. Dublin: Hodges \& Smith. ${ }^{36}$

b. 1831 - Otto AW. A Compendium of Human \& Comparative Pathological Anatomy. Transl. by JF. South. Lond: Fellowes. ${ }^{45}$

c. 1831 - Liston R. Elements of Surgery. Part 2. Lond: Longman, Rees, Ormes, Brown \& Green. ${ }^{46}$

d. 1832 - Cloquet J. Surgical Pathology. Transl. by JW. Garlick \& WC. Copperthwaite. Lond: Samuel Highley. ${ }^{47}$

e. 1832 - Mackintosh J. Principles of Pathology and Practice of Physic. 3rd Ed. Vol. 1. Edinburgh: Carfrae \& Son. ${ }^{41}$

f. 1833 - Alison WP. Outlines of Pathology. Edin: Blackwood..$^{35}$

g. 1834 - Hope J. Principles of Illustrations of Morbid Anatomy. Lond: Whittaker. ${ }^{48}$ h. 1835 - Davies T. Lectures on the Diseases of the Lungs \& Heart. Lond: Longman. ${ }^{26}$

i. 1835 - Hunter J. The Works of John Hunter. Ed by J.F. Palmer, Vol 1, Lond: Longman, Rees, Orme, Brown, Green and Longman. ${ }^{9}$

j. 1837 - Warren, JC. Surgical Observations on Tumors Boston. Crocker and Brewster. ${ }^{48}$

k. 1838 - Lizars J. A System of Practical Surgery. Part 2. Edin: Lizars. $^{49}$

Going back to the 1832 English translation of Cloquet's48 French work, titled "Surgical Pathology," what was striking was that "metastasis" was explained by way of the cellular basis of the transportation of inflammatory materials in the body. Next, let us consider the work of John Collins Warren ${ }^{48}$ (1778-1856). According to Haagensen's ${ }^{50} 1933$ voluminous exhibits, Warren's book was the first American treatise on tumors. How went Warren? In particular, he wrote as follows:

Examination of the scirrhous tumour, after being taken from the breast, presents different appearances in different subjects and different stages. When I have examined a specimen of small growth, and at an early period of its existence, proceeding from the surface inwards, and scraping away the fat of the breast, a number of white processes are seen radiated from the central nucleus. These at first seem to be mere cords, but on observing further, they proved to be membranous prolongations from the central nucleus to various parts of the breast. Coming to the nucleus itself, this is found to be hard and irregular, and requiring an incision. Cutting through this hard body, we find it grows more firm as we approach its central point, where its hardness is very great. On examining the section thus made, we find the circumference of the nucleus constituted by a membrane or cyst, which has different degrees of distinctness, and disappears at one part where its scirrhous substance is continuous with that of the breast.

Note should be taken of the above use of "nucleus" here for up to four times! Alas! It was not in terms of the microscope. Rather, it was in the same ordinary light that Bell ${ }^{23}$ in 1816 used "cells" twice in his own treatise.

\section{The forerunner stage}

This stage can be recognized as that which occurred between the just reviewed macroscopy era and the modern microscopy era. For instance, Ober ${ }^{51}$ recently recognized this interesting stage, namely, "Pathologists had examined Surgical Specimens before 1886, but until surgical anesthesia and asepsis became widely available, surgical specimens were limited in range." Indeed, the limitation in range was such that, as regards microscopy, the English translator of Muller's ${ }^{22}$ 1840 German work regretted that "the pathology of morbid tumours and fungoid growths is at present in its infancy." Incidentally, it was added significantly that "the part which cells sustain in the composition of all morbid growths has, however, recently acquired additional importance from the investigations of Schleiden and Schwann." The former authority worked on plants while the latter dealt with the analogy between animal and vegetable structures. This led to the firm confirmation of the observations "touching the development and growth of (morbid) tissues," i.e., the cellular structure proper. Little wonder that, in 1849, Bennett ${ }^{52}$ wrote his own tome: "On Cancerous and Cancroid Growths." Indeed, he lamented that "the account now to be given can only be considered as a sketch, any part of which may be erased, filled up, or corrected, according to the information obtained in future investigations." 


\section{Conclusion}

The development of surgical pathology is a field of continuing interest. It spanned a field which encompassed obtaining the surgical specimen, examining it, naming it, preserving it, writing books on it, and generally maturing with time and experience. Today, the stage is set for handing over to future teachers who had themselves been taught with surgical specimens obtained from parents whom they had seen in the clinic. ${ }^{53}$

\section{Acknowledgments}

None.

\section{Conflicts of interest}

Author declares that there is no conflict of interest.

\section{References}

1. Kalderon AE. The evolution of microscope design from its invention to the present days. Am J Surg Pathol. 1983;7(1):95-102.

2. Hayward OS. The history of oncology: Early Oncology And The Literature Of Discovery. Surgery. 1965;58:460-468.

3. Fisher ER, Herman CM. Historic milestones in cancer pathology. Semin Oncol. 1979;6(4):428-432.

4. Kardinal CG. An outline of the history of cancer. Mo Med. 1977;74(12):662-666

5. Sigerist HE. The historical development of the pathology and therapy of cancer. Bull NY Acad Med. 1932;8(11):642-653.

6. Ackerknecht EH. Historical notes on cancer. Med History. 1958;2:114-119.

7. Hodgkin T. A Catalogue of the preparations in the anatomical museum of Guy's Hospital. Watts Section III: London, UK; 1829. 359 p.

8. Rothstein WG. The evolution of pathology as a specially in American medicine. Med Care. 1979;17(10):975-988.

9. Hunter J. The works of John Hunter. In: Palmer JF (Ed.), Longman et al., London, UK; 1835. 1728-1793 p.

10. Norris W. Case of Fungoid Disease. Edin Med Surg J. 1820;16:562-565.

11. Friend J. The History of Physic; from the time of Galen, to the beginning of the Sixteenth Century. London, UK; 1725. 53-54 p.

12. Ie Dran HF. Operations in surgery. Transl by Thomas Gataker. C Hitch, London, UK; 1749. 269-303 p.

13. Macbride D. A Methodical introduction to the theory and practice of physics. In: Strahan W \& Cadell T, London, UK; 1772. 626 p.

14. Hey W. Practical observations in surgery: illustrated with cases. T Cadell, London, UK; 1803. 266 p.

15. Thomas R. The modern Practice of Physic. 9th ed. London, UK; 1828. $778 \mathrm{p}$.

16. Scarpa A. A treatise on the principal diseases of the eyes. Cadell \& Davies: London, UK; 1806. 525-534 p.

17. Cooper SA. On diseases of the breast. Lancet. 1824;2:704-725.

18. Dawson GP. A nosological Practice of Physic, embracing Physiology. Longman Hurst Rees Orme Brown and Green: London, UK; 1824. 278-279 p.

19. Pearson J. Practical observations on cancerous complaints. Johnson: London, UK; 1793.3 p.
20. Baillie M. The morbid anatomy of some of the most important parts of the human body. Johnson \& Nicol: London, UK; 1793.

21. Graves RJ. Observations on the Treatment of Various Diseases; 1834. 321-328 p.

22. Miller J. The principles of surgery. 2nd Ed. Adam and Black; 1850. 316-324 p.

23. Bell C. Surgical observations. Longman: London, UK. 1816;1:365-413.

24. Earle H. A case of diseased testicle, accompanied with disease with of the lungs and brain, and terminating fatally. Med-Chir Trans, Longmans: England; 1816. 59-79 p.

25. Todd RB. Disease of the liver: In the Cyclopaedia of Practical Medicine. In: Forbes J, et al. Supplement. Sherwood, Gilbert, and Piper, London, England; $1835.647 \mathrm{p}$.

26. Davies T. Lectures on the diseases of the lungs \& heart. Longman: London, UK; 1835. 304-305 p.

27. Travers B. The local diseases termed malignant. Med-Chir Trans. $1829 ; 15: 195-262$.

28. Carswell R. Diseases of the liver. In the cyclopaedia of practical medicine. In: J Forbes, et al. Sherwood, Gilbert, and Piper, London, UK; 1834. $665 \mathrm{p}$.

29. Crawford A. Experiments and observations on the matter of cancer. Philos Trans Roy Soc; 1790. 391-426 p.

30. Young S. An inquiry into the nature and action of cancer. R. Phill 1-2, London, UK; 1805.

31. Howard J. Practical observations on cancer. Hatchard J: London, UK; $1811.30 \mathrm{p}$.

32. The Edinburgh practice of physic, surgery, and midwifery. Surgery. In: Kearsley G, London, UK; 1803, 385 p.

33. Abernethy J. Surgical observations. Longman \& Rees: London, UK; 1804. 74 p.

34. Johnson CT. A practical essay on cancer. Callow: London, UK; 1810 $75 \mathrm{p}$.

35. Alison WP. Outlines of Pathology. Blackwood: Edin; 1833. 269 p.

36. Andral G. A Treatise on Pathological Anatomy. Transl. from the French by R. Townsend \& W. West. Hodges \& Smith, Dublin, USA; 1831. 443-444 p.

37. Kerr W. Fungus Haematodes: In the cyclopaedia of practical medicine. In: Forbes J, et al. Sherwood, Gilbert, and Piper, London, UK; 1833. $300 \mathrm{p}$.

38. Graves RJ. Observation on the treatment of various diseases. 1834;4:309-328.

39. Monro A. The morbid anatomy of the human gullet, stomach and intestines. Archibald Constable \& Co.: Edinburgh, Scotland; 1811. 321 p.

40. Bichat X. General anatomy. Shackell \& Arrowsmith: London, UK; 1824. $595 \mathrm{p}$.

41. Mackintosh J. Principles of Pathology and Practice of Physic. Edin Carfrae \& Son. 1832;1:280.

42. Bright R. Cases and observations connected with disease of the pancreas and duodenum. Med-Chir Trans; 1836. $300 \mathrm{p}$.

43. Home SE. Observations on cancer with connected Histories of the diseases. TN Longman: London, UK; 1805. 145 p.

44. Cooper AP. Illustrations of the diseases of the breast. Longman Rees \& Co.: London, UK; 1826.67 p. 
45. Otto AW. A compendium of human \& comparative pathological anatomy. Fellowes: London, UK; 1831. $355 \mathrm{p}$.

46. Liston R. Elements of Surgery. Longman Rees Ormes Brown \& Green: London, UK; 1831.

47. Cloquet J. Surgical Pathology. In: Garlick JW, Copperthwaite. Samuel Highley: London, UK; 1832. 46 p.

48. Warren JC. Surgical observations on tumors. Boston: Crocker and Brewster; 1837. 239 p.

49. Lizars J. A System of Practical Surgery. Lizars: Edin; 1838.
50. Haagensen CD. An exhibit of important books, papers, and memorabilia illustrating the evolution of the knowledge of cancer. Am J Cancer. $1933 ; 18: 42-126$.

51. Ober WB. American pathology in the 19th century: notes for the definition of a specialty. Bull NY Acad Med. 1976;52(3):326-347.

52. Bennett JH. On cancerous and cancroids growths. Edin: Sutherland; 1849. 43-46 p.

53. Boon AP, Smallman LA, Thompson H. Teaching surgical pathology at the Birmingham General Hospital. J Pathol. 1988;155(4):355-356. 